\title{
ОПТИМІЗАЦІЯ САМОСТІЙНОЇ РОБОТИ СТУДЕНТІВ-ФІЛОЛОГІВ ЗА КРЕДИТНО-МОДУЛЬНОЮ СИСТЕМОЮ ОРГАНІЗАЦІЇ НАВЧАЛЬНО-ВИХОВНОГО ПРОЦЕСУ
}

\footnotetext{
Бондар Л. А. Оптимізація самостійної роботи студентів-філологів за кредитномодульною системою організачї навчально-виховного процесу.

У статті розглянуто иляхи оптимізаиії самостійної роботи студентів-філологів в умовах сучасного педагогічного вишу, доповнено ї̈ змістові характеристики важсливого складника навчально-виховного прочесу.

Ключові слова: самостійна робота, кредитно-модульна система організації навчальновиховного процесу, модель особистісно зорієнтованого навчання, уміння і навички самостійної роботи.

Бондар Л. А. Оптимизаџия самостоятельной работьл студентов-филологов по кредитномодульной системе организации учебно-воспитательного прочесса.

В статье рассматриваются пути оптимизации самостоятельной работы студентовфилологов в условиях современного педагогического вуза, дополняются ее содержательные характеристики важной составляющей учебно-воспитательного проиесса.

Ключевые слова: самостоятельная работа, кредитно-модульная система организации учебно-воспитательного прочесса, модель личностно ориентированного обучения, умения и навыки самостоятельной работы.

Bondar L. Optimization of the independent work of students-philologists of credit-modular system of organizing the educational process.

This article considers the ways to optimization of students' independent work in the modern teaching of high school, its substantial characteristics of an important component of the educational process are completed here.

Key words: independent work, credit-module system of organizing the educational process, a model of personality-oriented learning, skills of independent work.
}

Постановка проблеми. Модернізація вищої педагогічної освіти в Україні здійснюється в умовах інтенсивної інтеграції до єдиного європейського освітнього і наукового простору, відтак зумовлює підвищення якості підготовки фахівця, висококваліфікованого і мобільного професіонала, конкурентоспроможного на ринку праці. Вищі заклади освіти покликані задовольняти соціальне замовлення суспільства на формування ерудованих та активних фахівців, які в умовах сьогодення можуть швидко і якісно вдосконалювати свою кваліфікацію, самостійно розвивати власний творчий потенціал.

Сучасна концепція освіти грунтується на принципі навчального пізнання, що реалізується моделлю особистісно зорієнтованого навчання, у процесі якого, за Л. Виготським, можливості навчання визначаються зоною найближчого розвитку, а необхідною умовою активності та розумового розвитку особистості $\epsilon$ така організація пізнавальної діяльності, яка сприяє максимально швидкому переходу зони найближчого розвитку на рівень актуального розвитку й виникнення нової зони найближчого розвитку із ширшими можливостями студента до наслідування, співробітництва й самостійності. 
Отже, у процесі діяльності має відпрацьовуватися раціональна технологія діяльності для отримання i використання визначеної системи знань, умінь і навичок, вироблятися певний стиль мислення, які кожній особистості нададуть змогу орієнтуватися у новій для неї ситуації i знаходити в ній ефективні варіанти діяльності. Модель такого навчання підпорядковується процесу засвоєння знань, умінь i навичок у вигляді сприйняття й осмислення кожної нової порції інформації, усвідомлення їі за допомогою розуміння - узагальнення і закріплення знань, умінь і навичок здатність застосовувати їх на практиці - виникнення потреби у нових.

Мета статті - окреслити шляхи оптимізації самостійної роботи студентів-філологів як важливої складової навчального процесу у сучасному педагогічному виші; конкретизувати етапи та іiі змістові характеристики в умовах кредитно-модульної системи організації дидактичного процесу.

Реформування системи національної освіти i перехід вишів до організації навчально-виховного процесу за Болонською системою поставили викладачів перед необхідністю орієнтувати студентів на самостійне опрацювання значної частини матеріалу за умови постійного консультування та збереження функцій контролю. Це зумовило новий методологічний підхід до організації самостійної пізнавальної діяльності студентів, опанування ними нових технологій, методик і засобів самонавчання й освіти.

Оптимізація самостійної роботи студентів у практиці вишів вимагає особливої уваги викладачів, оскільки тут $\epsilon$ найбільше недоліків. У дослідженнях українських (В. Буряк, В. Володько, Т. Іванова, М. Солдатенко, В. Ужик, Н. Чернігівська, М. Штокало та інших) i російських науковців (Б. Ссипов, М. Данилов, П. Підкасистий та інші) педагогів та працях психологів (Б. Ананьєв, Д. Богоявленський, Л. Виготський, І. Гальперін, Н. Менчинська, С. Рубінштейн та інші) наголошується, що причинами цих недоліків $\epsilon$ складність формування умінь i навичок самостійної роботи студентів, відсутність системності у цій діяльності, недостатня розробленість цього аспекту в педагогіці, необхідність чіткої переорієнтації в діяльності викладача, залежність розумового розвитку студентів, їхньої активності й самостійності у процесі навчання від володіння прийомами роботи і розумової діяльності тощо.

Практика засвідчує, що самостійна робота в умовах кредитномодульної системи організації навчально-виховного процесу у вищій школі спонукає студента до поглибленого вивчення теорії, до систематизації знань, сприяє вмінню застосовувати їх під час розв'язання практичних завдань, формує у студентів потребу постійного поповнення своїх знань шляхом самоосвіти, сприяє розвитку творчих здібностей та активізує розумову діяльність студентів, виховує інтелектуальні, морально-вольові якості (працелюбність, дисциплінованість і організованість); розвиває творчу активність, діловитість, зосередженість, ініціативність, наполегливість у досягненні поставленої мети, важливих для їхньої майбутньої професійної діяльності.

Студент, який прагне глибоко оволодіти обраною спеціальністю, має розуміти, що на заняттях викладач подає основи знань, виокремлює головні 
позиції дисципліни, які уможливлюють формування потреби до поглиблення й удосконалення знань із відповідної дисципліни, оскільки навчання як неперервний процес не завершується на лекції, семінарському, практичному чи лабораторному заняттях, як основних організаційних аудиторних формах навчання. 3 урахуванням означеного вище, в основі самостійної навчальної діяльності мають бути глибокі мотиваційні чинники, що спонукають особистість постійно прагнути до вдосконалення фахових знань, формування продуктивних способів розв'язання практичних професійних проблем в умовах сучасного динамічного соціуму та високих вимог до рівня трансформованого інформаційного суспільства.

Зміст самостійної роботи студентів із конкретної дисципліни визначається державним стандартом освітньої галузі, навчальною та робочою програмою вивчення дисципліни, забезпечується системою навчально-методичних засобів: основна література (підручники, посібники, конспект лекції викладача, навчальні та методичні посібники), додаткова література (наукова, фахова, монографічна, періодична), методичні матеріали (методичні рекомендації, окремі завдання та вказівки викладача щодо виконання самостійної роботи студентами).

Поряд із лекцією, семінаром, практичним заняттям та іншими формами навчання, самостійну роботу розглядають як окремий вид навчальних занять у відведений час дня за розпорядком вишу без безпосередньої участі викладача, однак за умови обов'язкового контролю ним цієї роботи. Дослідники характеризують самостійну роботу як навчальну діяльність студента, спрямовану на вивчення й оволодіння матеріалом навчального предмета без безпосередньої участі викладача.

Оскільки самостійна робота спрямована передовсім на активну розумову діяльність студента, яку він здійснює не тільки позааудиторно, а й на лекціях, семінарах, консультаціях, під час захисту курсових, дипломних, магістерських проектів, під час складання заліків, іспитів тощо, то їі можна вважати одним із основних методів засвоєння знань, формування вмінь i навичок. Прихильники цього підходу стверджують, що ця робота охоплює всю пізнавальну діяльність студентів (різні види i форми занять у навчальному процесі). На нашу думку, самостійна робота - спланована, активна, пізнавальна, організаційно i методично спрямована особиста діяльність студента для здобуття нових знань і вмінь без прямої допомоги викладача, проте за умови постійного педагогічного керівництва й контролю та оцінювання іiі результатів.

У цьому контексті самостійна робота розглядається як самостійне виконання завдань в аудиторії під керівництвом викладача та організація самостійної навчальної чи наукової діяльності студента у позааудиторний час. Як вид навчально-пізнавальної діяльності, іiі умовно поділяють на три види: доаудиторну, аудиторну, позааудиторну. 
Викладач визначає обсяг і зміст самостійної роботи, узгоджує іiі 3 іншими видами діяльності, розробляе засоби поточного та підсумкового контролю, аналізує результати самостійної навчальної роботи студента.

Під час вивчення дисципліни навчальним планом передбачено певну кількість годин на самостійне опрацювання окремих тем, робочою програмою визначено зміст і характер самостійних завдань із дотриманням таких вимог: а) виконувана самостійна робота має бути спрямована на досягнення основних навчально-виховних завдань, б) самостійне навчання має бути систематичним і систематизованим у контексті навчальних занять; в) на самостійну роботу можуть виноситися як частина теоретичного матеріалу, менш складного за змістом, який вивчається аудиторно, так i окремі практичні роботи, що не потребують безпосереднього керівництва викладача; г) важливу роль в організації самостійної роботи студентів відіграє інструктаж щодо її проведення та індивідуальні консультації.

Плануючи самостійну роботу студентів та розробляючи методичні рекомендації щодо іiі організації, необхідно враховувати той перелік знань, умінь і навичок, який передбачається освітньо-кваліфікаційною характеристикою спеціаліста. Кожен викладач в усіх формах навчально-виховного процесу для становлення майбутнього спеціаліста має виходити 3 місця і ролі відповідної дисципліни у формуванні знань, умінь і навичок студента. Самостійна робота має реалізуватися як обов'язковий складник сучасного навчально-виховного процесу, чітко спланована й організована викладачем чи вищим навчальним закладом (дистанційно).

Оновлення освітньої парадигми сучасного вишу зумовлює внесення коректив до завдань самостійної роботи - навчити студентів самостійно працювати 3 науковими та дидактичними джерелами; спонукати майбутніх фахівців творчо сприймати навчальний матеріал, осмислювати, прогнозувати шляхи застосування його на практиці; сформувати у студентів стійкі навички систематичної самостійної роботи у здобутті та узагальненні знань, виробленні вмінь та навичок; розвинути у студентства потребу в продуктивній самоосвіті.

Спостереження показують, що мотиви самостійної навчальної діяльності студента можуть бути різні: збагачення знань, розширення світогляду, усвідомлення наявної перспективи щодо реалізації певних знань, потреба кращого оволодіння майбутньою професією тощо. Ця діяльність буде найбільш результативною за умови особистісного інтересу, який пізніше стане внутрішньою потребою особистості.

У робочій навчальній програмі будь-якої дисципліни передбачено самостійну індивідуальну роботу студентів у позааудиторний час, яка охоплює такі види робіт: вивчення певної інформації: наприклад, засвоєння матеріалу теми, яка розглядається на лекції (робота за конспектом лекції, рекомендованою навчальною літературою); опрацювання джерел (обов'язкової та додаткової літератури), складання тез, конспектування фундаментальних робіт відповідно до програми навчальної дисципліни; дослідницька i 
пошукова діяльність (студіювання проблемних питань, проведення мовних експериментів, робота із аудіовізуальними засобами; написання рефератів, контрольних робіт, фіксованих виступів (тез, доповідей) на основі опрацювання різнотипних джерел та інших шляхів надходження інформації; підготовка курсових, дипломних, магістерських робіт; проведення наукових досліджень, підготовка наукових доповідей i повідомлень, написання розгорнутих чи коротких анотацій, статей; участь у навчальних, розвивальних та ін. іграх; складання картотек; тестування і самотестування.

Розпочинаючи вивчення навчальної дисципліни, студент має отримати інформацію про всі форми самостійної роботи з виокремленням обов'язкової і додаткової, форм самостійної роботи. Додаткову самостійну роботу можна ще розподілити на роботу в обов'язковому порядку і роботу за вибором студента, яка може передбачати, наприклад, такі види робіт, як: участь у наукових студентських конференціях, олімпіадах, семінарах, написання реферату із певної проблеми, огляд публікацій з означеної проблематики.

Аналіз наукових джерел із обраної проблеми уможливив виокремлення чотирьох рівнів самостійної діяльності студента: репродуктивні дії студента за поданим зразком; раціоналізаторська діяльність студента 3 відтворення інформації та використання уже відомих знань; дослідницька діяльність самостійного використання знань для розв'язання завдань; творча діяльність iз використанням знань для розв'язання нових, неординарних завдань, які $\epsilon$ важливим засобом вироблення у студентів навичок творчого пошуку і сприяють не тільки конкретизації та закріпленню знань, здобутих під час аудиторних занять, а й доповнюють, розширюють їх шляхом самостійної роботи.

Важливу роль в організації самостійної роботи відіграють зовнішні та внутрішні чинники, які впливають на характер, інтенсивність та результативність процесу самовиховання студентів та дають підстави для визначення шляхів його активізації. Чинниками зовнішнього впливу, на наш погляд, є: соціальне замовлення, що впливає на якість вищої освіти; освітня політика держави, спрямована на виховання свідомого громадянина, здатного до самостійної системної роботи; спрямування виховної діяльності університету; урахування специфіки підготовки студента-філолога; науково-методичне забезпечення виховної роботи зі студентами відповідно до навчальних планів і програм; гуманізація і демократизація суб’єкт-суб'єктних відносин у навчальному процесі; цілеспрямований вплив діяльності органів студентського самоврядування; самоорганізація навчальної діяльності студентом. До чинників внутрішнього впливу нами віднесено внутрішню позицію студента; рівень орієнтації мотиваційної сфери студента на самовдосконалення і самоорганізацію, розвиток його самосвідомості; індивідуально-психологічні особливості (наполегливість, відповідальність, емоційно-вольова сфера студента); характер і сукупність ціннісних орієнтацій студента.

У результаті наукового пошуку шляхів оптимізації самостійної роботи студентів-філологів нами розроблено модель активізації самовиховання майбутніх фахівців, компонентами якої є чотири основні взаємозумовлені і 
взаємопов'язані етапи: організаційно-мотиваиійний, інформаційно-змістовий, операційно-діяльнісний та інтеграційно-творчий. Зміст кожного із етапів реалізується через систему лекційно-практичних занять основних та запропонованого спецкурсів («Вступ до спеціальності» - I курс, «Основи самостійної роботи студента» - II курс, «Основи наукових досліджень» III курс, «Професійне мовлення» - IV курс).

Кожен із етапів передбачає цілеспрямовану роботу 3 актуалізації цінностей самовиховання у виховному просторі; збагачення змісту виховного компоненту педагогічних дисциплін концепціями розвитку особистості, технологіями самовиховання і самоудосконалення; запровадження інтегративнорефлексивних форм і методів стимулювання самовиховної діяльності студентів; формування досвіду самовиховання студента.

Задля стійкої мотивації самовиховної діяльності студентів-філологів на першому - організаиійно-мотиваиійному етапі - запропоновано проведення у позааудиторний час тренінгів, бесід, диспутів, виставок, конференцій, творчих зустрічей, вечорів, екскурсій, та систему лекційно-практичних занять спецкурсу «Вступ до спеціальності».

Другим інформачійно-змістовим етапом передбачено збагачення студентів теорією і методикою самовиховання через зміст спецкурсу «Основи самостійної роботи» та позанавчальної виховної роботи (проблемні лекції, семінари-практикуми, педагогічні ситуації, вікторини, конференції).

На третьому операщійно-діяльнісному етапі запропоновано роботу зі стимулювання самовиховної діяльності студентів через реалізацію змісту спецкурсу «Основи наукового дослідження», спрямованого на цілісне оволодіння студентами технологією самовиховання через інтерактивно-рефлексивні, творчі форми, методи та прийоми роботи, ділові ігри, тренінги, дискусії, діагностичні методики, творчі роботи, тести, конкурси, захисти проектів.

На четвертому етапі (інтеграиійно-творчому) передбачено систематичну роботу зі студентами для формування досвіду самовиховної діяльності на заняттях спецкурсу «Професійне мовлення» (підготовка творчих та наукових робіт, педагогічні (виробничі) практики, виступи на семінарах, конференціях тощо).

Висновки. Отже, оптимізація самостійної роботи студентів-філологів за пропонованою моделлю передбачає: планування відповідно до робочої програми організацію самостійної роботи студентів, власне, від якої насамперед залежать якість навчання студентів та ефективність їх майбутньої практичної діяльності; формування у студентів потреб і мотивів до активної творчої самостійної роботи; навчання студентів основ самостійної роботи, яка, як складова частина навчання, має всі атрибути, ознаки та властивості загального феномену людської діяльності: мотиваційні (ідеал, мотиви, інтереси); орієнтаційні (механізм визначення мети, планування та прогнозування діяльності); операційні (задатки, здібності, обдарованість, талант, уміння, навички); енергетичні (увага, воля, емоційний фон діяльності) та оцінювання результативності дій; керівництво і контроль за виконанням навчальних завдань. 
Окрім того, запропонована модель відображає динаміку розвитку самовиховної активності студентів-філологів, яку доцільно впроваджувати в навчально-виховний процес педагогічного вишу поетапно, охоплюючи аудиторну та виховну роботу (лекційно-практичні заняття, бесіди, диспути, тренінги, захисти проектів, проведення тематичних вечорів, конкурсів, свят, читацьких та наукових конференцій, реалізація методики самопізнання, самовдосконалення).

\section{Література}

1. Жулкевська В. Теоретико-методологічні основи дистанційного навчання / В. Жулкевська // Педагогічна психологія професійної освіти. - 2007. -№ 1. - С. 52-59.

2. Козаков В. Л. Самостоятельная работа студентов и ее информационнометодичекое обеспечение / В. Л. Козаков. - К., 1990. - 246 с.

3. Кредитно-модульна система підвищення якості освіти: [Національний гірничий університет] // Освіта України. - 2005. - №3. - С. 10-14.

4. Кулик Є. Дидактична характеристика процесу самоосвіти / Є. Кулик // Вища освіта України. 2006. -№13. - С. 10-13.

5. Плагов И. М. Пути совершенствования самостоятельной работы студентов в вузе: [учеб. пособ. для ун-тов, вузов, ф-тов повыш. квалиф. препод.] / И. М. Плагов, Т. И. Парубочая. -Челябинск: ЧГТУ, 1991. - 123 с.

6. Саулина О. П. Самостоятельная работа студентов как основа повышения эффективности их будущей профессиональной деятельности / О. П. Саулина, В. Н. Вяткина // Подготовка студентов факультета физической культуры к профессиональной деятельности. - М., 1991. - С. 114-121.

7. Середа I. В. Педагогічна підготовка вчителя в сучасному університеті / I.B. Середа // Неперервна професійна освіта : теорія і практика: [науково-методичний журнал]. - Київ, 2003. - Вип. 2. - С. 27-33.

Стаття надійшла до друку 10.05.2012 p.

УДК 378.091.33'026

С. М. Богомаз-Назарова, кандидат пед. наук, ст. викладач, Кіровоградський ДПУ ім. В. Винниченка

\section{МІЖПРЕДМЕТНІ ЗВ'ЯЗКИ ЯК ДИДАКТИЧНА УМОВА ПІДВИЩЕННЯ ЯКОСТІ ПІДГОТОВКИ МАЙБУТНІХ УЧИТЕЛІВ}

Богомаз-Назарова С. М. Міжпредметні зв'язки як дидактична умова підвищення якості підготовки майбутніх учителів.

У статті здійснено аналіз міжпредметних зв'язків у методичній літературі як важливої передумови підвищення ефективності навчання майбутніх учителів.

Ключові слова: міжпредметні зв'язки, навчальний прочес, майбутні вчителі.

Богомаз-Назарова С. М. Межпредметные связи как дидактическое условие повышения качества подготовки будущих учителей.

В статье сделан анализ межпредметных связей в методической литературе как важной составной при повышении эффективности обучения будущих учителей.

Ключевые слова: межпредметные связи, процесс обучения, будущие учителя.

Bogomaz-Nazarov S. Interdisciplinary communication as a condition for improving the quality of didactic training of future teachers.

In this article the analysis of intersubject connections is examined in methodical literature as important component at an increase efficiency of teaching.

Key words: intersubject connections, educational process, future teachers. 